\title{
Próteses auditivas: avaliações objetivas e subjetivas em usuários de amplificação linear e não-linear***
}

\author{
Hearing aids: objective and subjective evaluations of linear and \\ nonlinear amplification users
}

\author{
Letícia Pimenta Costa* \\ Maria Cecília Martinelli Iório***
}

\begin{abstract}
*Fonoaudióloga. Mestre em Ciências pela Universidade Federal de São Paulo - Escola Paulista de Medicina. Professora do Curso de

Fonoaudiologia da Faculdade de Medicina da Universidade Federal de Minas Gerais. Endereço para correspondência: Rua Ouro Preto, 1275 - Apto. 04 - Belo Horizonte - MG - CEP 30170-041

(lepcosta@uai.com.br).

**Fonoaudióloga. Doutora em Distúrbios da Comunicação Humana pela Universidade Federal de São Paulo - Escola Paulista de Medicina. Professora Adjunta do Curso de Fonoaudiologia da Universidade Federal de São Paulo - Escola Paulista de Medicina.
\end{abstract}

***Trabalho Realizado na Universidade Federal de São Paulo Escola Paulista de Medicina.

Artigo de Pesquisa

Artigo Submetido a Avaliação por Pares

Conflito de Interesse: não

Recebido em 18.11.2004

Revisado em 17.12.2004; 30.05.2005; 24.01.2006; 20.03.2006

Aceito para Publicação em 20.03.2006.

\begin{abstract}
Background: sensorineural hearing impaired individuals benefit themselves with the use of nonlinear amplification, once the compression tries to reestablish the sensation of normal loudness. However, the literature is still controversial in relation to the benefits for speech recognition in users of linear and nonlinear hearing aids. Aim: for this reason, the purpose of this study was to compare the performance of linear and nonlinear hearing aid users through objective and subjective evaluations, verifying the best circuit for hearing adaptation and speech recognition in silence and in noise. Method: 21 bilateral hearing aid users, who had been using the hearing aid for at least 3 months, with 12 to 64 years of age and with mild to moderate-severe hearing losses were studied according to the type of amplification used, forming two groups: linear group composed by 10 linear hearing aid users; and nonlinear group, composed by 11 nonlinear hearing aid users. Speech recognition tests were applied in silence and in noise, as well as the International Outcome Inventory of Hearing Aids questionnaire. Results: statistically significant differences were not observed between the groups for the speech recognition tests, in silence and in noise, and for the questionnaire. Conclusion: it can be concluded that no difference exists in the performance of linear and nonlinear hearing aids users, regarding the objective evaluations (speech tests) and the subjective evaluations (questionnaire), that indicate a better adaptation or a better speech recognition in silence or in noise.
\end{abstract}

Key Words: Hearing Aid; Hearing Loss; Audiometry Speech; Questionnaires

\section{Resumo}

Tema: os indivíduos com perda auditiva neurossensorial se beneficiam muito com o uso da amplificação não-linear, uma vez que a compressão tenta restabelecer a sensação de intensidade normal. No entanto, a literatura ainda é controversa em relação aos benefícios para o reconhecimento de fala em usuários de próteses auditivas lineares e não-lineares. Objetivo: comparar o desempenho de usuários de próteses auditivas lineares e não-lineares por meio de avaliações objetivas e subjetivas, verificando o circuito que mais favorece uma melhor adaptação auditiva e reconhecimento de fala no silêncio e no ruído. Método: 21 usuários de próteses auditivas bilateral há pelo menos três meses, com idades compreendidas entre 12 e 64 anos, e perdas auditivas de grau leve a moderadamente severo, foram estudados conforme o tipo de sua amplificação, formando dois grupos: grupo linear, composto por 10 usuários de próteses auditivas lineares; e grupo não-linear, composto por 11 usuários de próteses auditivas não-lineares. Foram realizados os testes de reconhecimento de fala no silêncio e no ruído, e aplicado o questionário Internacional de Avaliação das Próteses Auditivas. Resultados: não foram observadas diferenças estatisticamente significantes nos testes de reconhecimento de fala no silêncio e no ruído, nem no questionário aplicados, quando comparamos os grupos de usuários de próteses auditivas lineares e não-lineares. Conclusão: pode-se concluir que não há diferença entre o desempenho dos usuários de próteses auditivas lineares e nãolineares nas avaliações objetivas (testes de fala) e subjetivas (questionário) aplicadas, que indique uma melhor adaptação auditiva ou favoreça o reconhecimento de fala tanto no silêncio quanto no ruído. Palavras-Chave: Auxiliares de Audição; Perda Auditiva; Audiometria da Fala; Questionários. 


\section{Introduction}

Once the main function of the human hearing is to enable oral communication, the greatest loss caused by the hearing disorder is related to the abilities of speech recognition, which seriously harms the communicative needs of the individual and his social relations. In order to reestablish the communicative function of the hearing impaired, all kinds of technology involved for the best performance of hearing aids aims at new strategies to enhance speech reception. The development that has occurred until now has been conducive to a better hearing and speech of the hearing impaired, especially when he is in quiet surroundings. However, the performance that the individual shows in noisy places has not yet reached a satisfactory level of improvement.

Human hearing is limited by the lowest levels of sound intensity which an individual is cabaple of perceiving and the highest levels of sound intensity, at which one feels hearing discomfort. The hairy cells of the cochlea are responsible for the modulation of the sound information that reach them, which then become sufficiently intense to be perceived and not to cause hearing discomfort. Considering the cochlear physiology, systems of sound compression were developed in such a way as to favor the hearing of soft sounds, which are not perceived by the hearing impaired and to control the levels of high sound pressure that may cause discomfort to the user of amplification, with a minimum possible of sound distortion (Lindley, 2002).

Presently, we can define two different types of sound amplification based on how the gain is provided. When there is no gain variation, that is, the quantity of the amplification is the same for all incoming sound intensities, we classify it as linear hearing aids. On the other hand, when there is an automatic alteration in the parameters of the amplification, especially of the gain, these aids are classified as nonlinear.

The hearing aids that show variation of gain depending on the input level are considered nonlinear. Hearing aids with dynamic compression or WDRC (Wide Dynamic Range Compression) characterized by low threshold and compression ratio are included in this group. These hearing aids process the most important sounds of daily life nonlinearly, including speech (Menegotto and Iório, 2003). Thus, different gain values are supplied with different incoming sound intensities, that is, the lowest and the least perceptive sounds show a higher gain (linear amplification), whereas average and the most intense sounds show a lower gain, as a result of the compression action.

The individuals who have neurosensorial hearing loss benefit a lot from the use of nonlinear amplification, once the compression tries to reestablish the sensation of normal intensity. It is believed that modification of acoustic signal provided by the automatic control of gain, which is widely used by the majority of the producers of hearing aids, enhances the performance in terms of audibility, comfort and recognition of speech (Jenstad et al., 1999; Jenstad et al., 2000). However, there is still much controversy around this subject in the literature, since various different parameters characterize a compression system, among which are the compression threshold, compression ratio, frequencies ranges, attack times and recovery (Souza, 2002).

Thus, we understand that the adaptation of the hearing aid devices needs to be individual and personal, respecting the audiological characteristics of each individual and their auditive needs, in order to provide the desired amplification.

There are many ways to evaluate the result of the hearing aid fitting, which are based on objective and subjective tests that measure and estimate the performance, benefit, satisfaction and the use of the hearing aid (Almeida, 2003). Presently, many studies, including in Brazil, have valued the application of questionnaires and speech recognition tests as a way of evaluating individuals in the adaptation process of hearing aids (Bucuvic and Iório, 2003; Bucuvic and Iório, 2004; Dan and Iório, 2004; Almeida, Taguchi, 2004). Thus, the present study, by means of objective and subjective tests, evaluated users of linear and nonlinear hearing aid, in order to compare the obtained results, verifying the circuit that most favors a better auditive adaptation and speech recognition in quiet and in noise.

\section{Method}

This study was carried out in the Integrated Nucleus of Treatment, Research and Teaching of Audiology (NIAPEA) of the Universidade Federal de São Paulo - Escola Paulista de Medicina, only after approval by the Committee of Ethics in Research from the same institution, protocol no. 0231/04. All individuals of the sample or those who are responsible, when they are under 18 years old, signed an informed consent form, for a voluntary participation in the study. 
The criteria for the selection of the patients for this study were:

1. Ages ranging from 12 to 65 .

2. Subjects with symmetric neurosensorial hearing loss, from a mild to moderately severe (average of audibility thresholds from $70 \mathrm{~dB}$ NA in the frequencies of 500, 1,000, 2,000 Hz).

3 . Hearing loss acquired in the post-lingual period. 4. Hearing aids users fitting bilaterally with identical models for at least three months.

5. Hearing aids acquired at São Paulo Hospital, through the program of the Federal Government of the Adaptation of Hearing Aids - Law 432-00).

6 . The absence of perceptible cognitive or speech alterations.

In this manner, 21 patients took part in this study, of whom 13 were male and eight female, with ages ranging from 12 to 64 and an average of 41 , who had fitted hearing aid bilaterally for at least three months, with an average use time of 16 months. With relation to the degree of hearing loss, three of them were mild, eight moderate and 10 moderately severe. These patients were gathered according to the type of amplification that their hearing aids had:

1. LG: group of linear hearing aids users.

2-NLG: group of nonlinear hearing aids users, or WDRC.

According to Menegotto and Iório's (2003) description, for purposes of classification of a hearing aid as either linear or nonlinear, the manner in which speech is processed was taken into consideration. In this manner, linear hearing aids were considered those which presented the same gain for each speech signal, regardless of the input level, including the aids that use limitation by compression or peak cuts as a way of limiting the maximum output sound. The nonlinear hearing aids, on the other hand, presented varied gain according to the input level, with the great majority of sounds, including those of speech, amplified in a nonlinear manner. These hearing aids presented low threshold and compression ratio.

The LG group was composed of 10 patients with linear hearing aid fitting, of whom 4 were females and 6 males, with ages ranging from 14 to 64 and an average of 47.6 years old, and an average use time of 9.4 months. As for hearing loss, all of them presented neurosensorial loss, of whom five presented moderate degree and five moderately severe. As concerns the hearing aid that they used, all of them presented compression as a way of controlling maximum output. The regulations were maintained according to the usual adaptation, which was performed for each individual.

The NLG group was composed of 11 patients with nonlinear hearing aid fitting, of whom four were females and seven males, with ages ranging from 12 to 49 and an average of 34.5 years old, and an average use time of 5.7 months. As for hearing loss, all of them presented neurosensorial loss, of whom three presented mild, three moderate and five moderately severe. Regarding the hearing aid, the compression characteristics were diverse, since the devices differed according to the model, brand and technology, with no regulations that permitted the establishment of evaluation parameters as for the threshold and compression ratio. However, all hearing aid presented, as a way of limiting maximum output, by compression. The regulations were maintained according to the previous users fitting.

The data gathering was carried out in two stages, on the same day:

1. Sentence Recognition Threshold in Quiet - SRT in quiet and Sentence Recognition Threshold in Noise - SRT in noise (Costa, 1998).

2. Filling out of the International Outcomes Inventory for Hearing Aids (IOI-HA).

\section{Sentence-recognition threshold research}

The evaluation of speech recognition threshold was made with the application of Sentences in Portuguese Test (Costa, 1998). The speech material was presented in quiet (SRT in quiet) as well as in noise (SRT in noise):

1. SRT in quiet: presentation of the sentences from 1 to 10 from the list $1 \mathrm{~B}$, without competitive noise. 2. SRT in noise: presentation of the sentences from 1 to 10 from the list $2 \mathrm{~B}$, with the competitive noise.

Before carrying out the test, a training with the patient in quiet and noise was done, using the initial sentences from the list 1A with the same intensity of the applied test to guarantee the patient's comprehension during the given task.

The procedure used for the application of the test was the "sequential, adaptive or risingdescending strategy" as suggested by the author of the test. The Speech Recognition Threshold (SRT) was determined this way, that is, the 
necessary level for the individual to identify correctly around $50 \%$ of given speech stimuli in quiet (SRT in quiet) as well as in the presence of ipsilateral competitive noise (SRT in noise).

According to the adopted strategy, the application of the test consisted of the presentation of a speech stimulus with a determined intensity. When the response was correct, the intensity of the presentation of the next stimulus was decreased. When the response was incorrect, the intensity of the presentation of the next stimulus was increased. Intervals of $4 \mathrm{~dB}$ were used until the first change in the response type and then the intervals of the presentation of stimuli were of $2 \mathrm{~dB}$ among themselves until the end of the list.

An answer was considered correct only when the individual repeated the whole presented sentence without any mistake or omission.

For the SRT in quiet and SRT in noise research, the first sentence of each list was presented with an intensity of $65 \mathrm{~dB} \mathrm{~A}$, since all individuals of the sample, using their hearing aids, had sufficient hearing thresholds to receive the speech stimulus at this intensity. On the other hand, for the application of SRT in noise, noise with a fixed intensity of $65 \mathrm{~dB}$ A was used, in a way that the test started with a speech noise ratio (SNR) of $0 \mathrm{~dB}$.

The levels of presentation of each sentence were written down during the evaluation. The average of these values was calculated from the levels of presentation of each sentence in which the first change in response occurred, until the level of presentation of the last sentence in the list, thus determining the sentence-recognition threshold.

The levels of presentation of each sentence were written down during the evaluation in a specific protocol. The average of these values was calculated since the levels of presentation of each sentence in which the first change in response occurred, until the level of the presentation of the last sentence in the list.

For the calculation of the SNR, SRT in noise was subtracted from the presented noise intensity, in this case, $65 \mathrm{~dB} \mathrm{~A}$, bearing in mind that the SNR corresponds to the difference, in $\mathrm{dB}$, between the value of SRT in noise (average of the intensity of the speech presentation in the presence of noise) and the value of competitive noise used.

The speech tasks were performed in open field, thus evaluating the binaural hearing of the bilaterally hearing aid, positioned in front of the loud-speaker at a distance of one meter to $0^{\circ}$ azimuth.

Each speech sample as well as the noise used were gouged in $\mathrm{dB}$ A using the Radio Shack Sound
Level Meter decibelimeter. As suggested by Costa (1998), the levels of sound pressure were measured, in which both speech and noise reached the tested individual's ear. The decibelimeter was positioned in a medium point between the ears, at a distance of one meter from the loudspeaker. For the measurements we used the A scale with quick responses, since it is the most indicated one for the measurement of continual noises and for the determination of extreme values of intermittent noises.

The levels of sound pressure both for the noise and speech were observed separately. In order to obtain the level of noise in the open field, its intensity among modulations was measured, as it is a continual sound which presents a small modulation of $1 \mathrm{~dB}$. Since we have a difference of $30 \mathrm{~dB}$ between the most and the least intense sound in speech, a medium value of reference was considered, which was obtained through the calculation of the average values of the peaks of highest amplitude of each sentence in the list.

After this, the volume unit (V.U.) was adjusted in the zero position during the presentation of a pure tone at $1,000 \mathrm{~Hz}$ which was recorded in the beginning of the CDs to guarantee the reproducibility of the presentation conditions.

Regarding the results of sentence recognition thresholds, both in quiet and in noise, these were analyzed and compared statistically, using the Mann-Whitney test, with a significance of 5\%. It was also observed whether there was any relation between the user's age, adaptation time, SRT, and SNR by means of Pearson's Correlation. The Pearson's Correlation was used to measure how interconnected the variables are, that is, how related one is to the other. The results are given in percentage, in which both positive and negative values can be observed.

The positive correlation means that as the value of the variable increased the other one correlated to this also increased proportionally. However, the negative correlation means inversely proportionate variables, in other words, as the value of one increased, the other decreased, or vice versa.

Because there are so many possible variables, in this study the result of the correlation was shown in matrix, forming the so called Correlation Matrix.

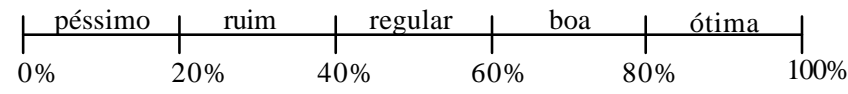


The international outcomes inventory for hearing aids

The filling out of the IOI-HA was done with the direct guidance of the researcher together with the individual, in order to guarantee the comprehension of questions and responses. The questionnaire, which was made up of eight questions, evaluated the result of the hearing aid fitting in a subjective way under these aspects: 1-Use; 2-Benefit; 3Residual activity limitation; 4-Satisfaction; 5Residual participation restriction; 6-Impact on others; 7-Quality of life. The eighth question of the questionnaire helped to estimate the level of hearing difficulty that the patient presented without the use of hearing aid.

The questionnaire offered the option of five responses graded from left to right, in such a way that the first option referred to a worse performance, graded one; the last option showed a better performance, graded five. The subject was asked to opt for only one response, the one that best described the result of the hearing aid fitting.

The eighth question was necessary just to observe the level of hearing difficulty of the subject. The responses of this questions were grouped according to the performed score. The individuals that scored one or two were included in group A, representing those who believed that they had a moderately severe or severe hearing difficulty; the individuals that scored three or four were included in group B, representing those who considered their hearing difficulty as mild or moderate; and those who scored five were included in group $\mathrm{C}$ and they believed that they did not have any hearing difficulty.

The analysis of the IOI-HA questionnaire was done by studying the responses of each item individually and grouped, with the results compared between the groups LG and NLG. Thus, the following was considered: the score of each question, the total score obtained in the first seven questions, and the score obtained when the factors 1 and 2 of the questionnaire are considered (Cox and Alexander, 2002). The factor 1 referred to the joint analysis of the items 1,2, 4, and 7, showing how the relation between the user and his hearing aid is. The factor 2 referred to the analysis of questions 3,5 and 6 , showing the relation between the user and his device.

Regarding the score obtained in each analysis, it is important to emphasize that the first seven items of the questionnaire have the minimum score of one and maximum score of five. The total score involves the response of the first seven items, making up a minimum score of seven and a maximum of 35 . The analysis of Factor 1 corresponds to the sum of four items, making up a minimum four, and a maximum 20 points in total and the Factor 2 corresponds to the sum of three items, making up a minimum three and a maximum of 15 points in total. A higher score shows better results regarding the hearing aid fitting.

The analysis of the question eight, which estimates the level of subjective hearing difficulty, was performed in each sample and compared with the score of each question of the questionnaire, the total score, and the factors 1 and 2 . The analysis of the questionnaire was performed by using the Mann-Whitney technique, with a significance of $5 \%$.

\section{Results}

The results of sentence recognition threshold (SRT) in quiet and the SNR, considering the values of the average, median, pattern deviation, size, maximum and minimal limits and the p-value obtained through Mann-Whitney test, thus establishing a comparison between the linear and nonlinear hearing aid are as follows (Table 1).

TABLE 1. Values of the average, mediean, pattern deviation, size, inferior and superior limits, and p-value of srt in quiet and snr in linear and nonlinear hearing aid users.

\begin{tabular}{|c|c|c|c|c|}
\hline \multirow[t]{2}{*}{ Usuários de AASI } & \multicolumn{2}{|c|}{ LRSS } & \multicolumn{2}{|c|}{$\mathrm{S} / \mathrm{R}$} \\
\hline & linear & não-linear & linear & não-linear \\
\hline média & 50,56 & 43,34 & $-2,75$ & $-2,37$ \\
\hline mediana & 47,4 & 43 & -4 & $-2,6$ \\
\hline desvio-padrão & 13,81 & 7,73 & 5,10 & 2,97 \\
\hline tamanho & 10 & 11 & 10 & 11 \\
\hline limite Inferior & 42,00 & 38,77 & $-5,91$ & $-4,13$ \\
\hline limite Superior & 59,12 & 47,90 & 0,41 & $-0,62$ \\
\hline p-valor & \multicolumn{2}{|c|}{0,150} & \multicolumn{2}{|c|}{0,836} \\
\hline
\end{tabular}

Legend: HA - hearing aid; SRT: sentence recognation threshold; SNR: speech noise ratio. 
We then searched if there was any correlation among the variables of the user's age, time of hearing aid fitting, SRT in quiet and SNR, in each sample. We correlated the age of the user with the results of SNR in the same way by considering the groups of linear and nonlinear hearing aid. For such, we applied Pearson's Correlation test and the analyzed results according to the Correlation Matrix, which is described in the chapter of Method. These data are available in table 2 and 3, respectively.
The results of IOI-HA are shown in Table 4 and 5. We used Mann-Whitney statistical test for all the analyzes done.

The table 4 refers to the analysis of the score which was obtained separately in each item of the questionnaire, the total score (sum of obtained points in the items from one to seven), Factor 1 and Factor 2, by comparing the circuit type of each hearing aid user (linear X nonlinear).

TABLE 2. Correlation among the age, fitting time to the hearing aid, the srt in quiet and the snr in hearing aids users.

\begin{tabular}{c|c|c|c}
\hline Usuários & Idade & Tempo & LRSS \\
\hline tempo & $32,7 \%$ & & \\
LRSS & $30,1 \%$ & $28,0 \%$ & $51,9 \%$ \\
S/R & $15,1 \%$ & $16,0 \%$ & \\
\hline
\end{tabular}

Legend: SRT - sentence recognition threshold; SNR: speech noise ratio.

TABLE 3. Correlation between the age and SNR in hearing aid users.

\begin{tabular}{c|c|c}
\hline Usuários & S/R Linear & S/R Não-Linear \\
\hline Idade & $44,5 \%$ & $-30,0 \%$ \\
\hline
\end{tabular}

Legend: Linear SNR - speech noise ratio in linear hearing aid users nonlinear SNR - speech noise ratio in nonlinear hearing aid users.

TABLE 4. Comparison of ioi-ha in linear and nonlinear hearing aid users, considering the score obtained in each item, the total score, factors 1 and 2

\begin{tabular}{|c|c|c|c|c|c|c|c|c|}
\hline Variáveis & AASI & Média & Mediana & Desvio Padrão & Tamanho & $\begin{array}{l}\text { Limite } \\
\text { Inferior }\end{array}$ & $\begin{array}{c}\text { Limite } \\
\text { Superior }\end{array}$ & P-valor \\
\hline \multirow{2}{*}{$\mathrm{I}-1$} & NL & 4,45 & 5 & 0,69 & 11 & 4,05 & 4,86 & \multirow{2}{*}{0,894} \\
\hline & $\mathrm{L}$ & 4,50 & 5 & 0,85 & 10 & 3,97 & 5,03 & \\
\hline \multirow{2}{*}{$\mathrm{I}-2$} & NL & 4,18 & 4 & 0,87 & 11 & 3,67 & 4,70 & \multirow{2}{*}{0,244} \\
\hline & $\mathrm{L}$ & 4,60 & 5 & 0,70 & 10 & 4,17 & 5,03 & \\
\hline \multirow{2}{*}{$\mathrm{I}-3$} & NL & 4,09 & 4 & 0,83 & 11 & 3,60 & 4,58 & \multirow{2}{*}{0,828} \\
\hline & $\mathrm{L}$ & 4,00 & 4 & 1,05 & 10 & 3,35 & 4,65 & \\
\hline \multirow{2}{*}{$\mathrm{I}-4$} & NL & 4,55 & 5 & 0,93 & 11 & 3,99 & 5,10 & \multirow{2}{*}{0,478} \\
\hline & $\mathrm{L}$ & 4,80 & 5 & 0,63 & 10 & 4,41 & 5,19 & \\
\hline \multirow{2}{*}{$\mathrm{I}-5$} & NL & 4,09 & 4 & 0,94 & 11 & 3,53 & 4,65 & \multirow{2}{*}{0,792} \\
\hline & $\mathrm{L}$ & 4,20 & 4,5 & 0,92 & 10 & 3,63 & 4,77 & \\
\hline \multirow{2}{*}{ I-6 } & NL & 4,55 & 5 & 0,52 & 11 & 4,24 & 4,85 & \multirow{2}{*}{0,275} \\
\hline & $\mathrm{L}$ & 4,10 & 4,5 & 1,20 & 10 & 3,36 & 4,84 & \\
\hline \multirow{2}{*}{$\mathrm{I}-7$} & NL & 4,36 & 4 & 0,67 & 11 & 3,97 & 4,76 & \multirow{2}{*}{0,890} \\
\hline & $\mathrm{L}$ & 4,30 & 5 & 1,34 & 10 & 3,47 & 5,13 & \\
\hline \multirow{2}{*}{$\mathrm{I}-8$} & NL & 1,91 & 2 & 1,04 & 11 & 1,29 & 2,53 & \multirow{2}{*}{0,837} \\
\hline & $\mathrm{L}$ & 2,00 & 2 & 0,94 & 10 & 1,42 & 2,58 & \\
\hline \multirow{2}{*}{ ST } & NL & 30,27 & 30 & 3,26 & 11 & 28,35 & 32,20 & \multirow{2}{*}{0,899} \\
\hline & $\mathrm{L}$ & 30,50 & 31 & 4,79 & 10 & 27,53 & 33,47 & \\
\hline \multirow{2}{*}{$\mathrm{F} 1$} & NL & 17,55 & 18 & 2,58 & 11 & 16,02 & 19,07 & \multirow{2}{*}{0,559} \\
\hline & $\mathrm{L}$ & 18,20 & 19,5 & 2,44 & 10 & 16,69 & 19,71 & \\
\hline \multirow{2}{*}{ F2 } & NL & 12,73 & 12 & 1,42 & 11 & 11,89 & 13,57 & \multirow{2}{*}{0,678} \\
\hline & $\mathrm{L}$ & 12,30 & 13 & 3,02 & 10 & 10,43 & 14,17 & \\
\hline
\end{tabular}

Legenda: L: linear; NL: não-linear; I: item; ST: soma total; F1: Fator 1; F2: Fator 2. 
In table 5, we considered the obtained responses in item eight, which defines the perception that the individual has in his own hearing loss. The questionnaire about the amplification type of each individual was not studied, but a comparison of the item eight considering the score obtained in each item, the total score, and the factors 1 and 2 were studied throughout the sample.

TABLE 5. Comparison of the hearing perception that the individual has in his own hearing loss (the result obtained in the eighth item of ioi-ha), considering the obtained score in each item, the total score, factors 1 and 2 in all users.

\begin{tabular}{|c|c|c|c|c|c|c|c|c|}
\hline Variáveis & Item 8 & Média & Mediana & $\begin{array}{l}\text { Desvio } \\
\text { Padrão } \\
\end{array}$ & Tamanho & $\begin{array}{l}\text { Limite } \\
\text { Inferior }\end{array}$ & $\begin{array}{c}\text { Limite } \\
\text { Superior } \\
\end{array}$ & P-valo \\
\hline \multirow{2}{*}{$\mathrm{I}-1$} & A & 4,43 & 5 & 0,76 & 14 & 4,03 & 4,82 & \multirow{2}{*}{0,605} \\
\hline & B & 4,57 & 5 & 0,79 & 7 & 3,99 & 5,15 & \\
\hline \multirow{2}{*}{$\mathrm{I}-2$} & A & 4,29 & 4,5 & 0,83 & 14 & 3,85 & 4,72 & \multirow{2}{*}{0,403} \\
\hline & B & 4,57 & 5 & 0,79 & 7 & 3,99 & 5,15 & \\
\hline \multirow{2}{*}{$\mathrm{I}-3$} & A & 4,21 & 4,5 & 0,89 & 14 & 3,75 & 4,68 & \multirow{2}{*}{0,244} \\
\hline & B & 3,71 & 3 & 0,95 & 7 & 3,01 & 4,42 & \\
\hline \multirow{2}{*}{$\mathrm{I}-4$} & A & 4,71 & 5 & 0,83 & 14 & 4,28 & 5,15 & \multirow{2}{*}{0,479} \\
\hline & B & 4,57 & 5 & 0,79 & 7 & 3,99 & 5,15 & \\
\hline \multirow{2}{*}{ I-5 } & A & 4,36 & 4,5 & 0,74 & 14 & 3,97 & 4,75 & \multirow{2}{*}{0,176} \\
\hline & B & 3,71 & 4 & 1,11 & 7 & 2,89 & 4,54 & \\
\hline \multirow{2}{*}{ I-6 } & A & 4,50 & 5 & 0,85 & 14 & 4,05 & 4,95 & \multirow{2}{*}{0,145} \\
\hline & B & 4,00 & 4 & 1,00 & 7 & 3,26 & 4,74 & \\
\hline \multirow{2}{*}{ I-7 } & A & 4,36 & 4,5 & 0,74 & 14 & 3,97 & 4,75 & \multirow{2}{*}{0,502} \\
\hline & B & 4,29 & 5 & 1,50 & 7 & 3,18 & 5,39 & \\
\hline \multirow{2}{*}{ ST } & A & 30,86 & 31 & 3,88 & 14 & 28,82 & 32,89 & \multirow{2}{*}{0,622} \\
\hline & B & 29,43 & 30 & 4,24 & 7 & 26,29 & 32,57 & \\
\hline \multirow{2}{*}{$\mathrm{F} 1$} & A & 17,79 & 18,5 & 2,58 & 14 & 16,44 & 19,14 & \multirow{2}{*}{0,878} \\
\hline & B & 18,00 & 19 & 2,45 & 7 & 16,19 & 19,81 & \\
\hline \multirow{2}{*}{$\mathrm{F} 2$} & A & 13,07 & 13,5 & 2,23 & 14 & 11,90 & 14,24 & \multirow{2}{*}{0,092} \\
\hline & B & 11,43 & 11 & 2,07 & 7 & 9,89 & 12,96 & \\
\hline
\end{tabular}

Legenda: I: item; ST: soma total; F1: fator 1; F2: fator 2; A: referente ao grupo A - dificuldade auditiva moderadamente severa a severa; B: referente ao grupo B - dificuldade auditiva leve a moderada.

\section{Discussion}

Performances in Sentence Recognition Threshold in quiet and in noise tests were analyzed in each group, in which the SNR was established. The results of the International Outcomes Inventory for Hearing Aids (IOI-HA) were also analyzed.

The SRT in quiet is a test which evaluates the lowest level of sound pressure at which an individual is capable of recognizing a sentence in quiet. Thus, it is an evaluation of sound amplification for low intensity sounds. The average values obtained in SRT in quiet test in groups LG and NLG were $50.56 \mathrm{~dB}$ A and $43.34 \mathrm{~dB}$ A, respectively (Table 1). In spite of the best SRT in quiet obtained in the nonlinear hearing aid user's group, the statistical analysis performed $(p=0,150)$ did not show significant differences between the groups studied.

Our findings are in accordance with Humes et al. (2004), who did not find any difference between the linear hearing aid and WDRC when they studied the word and sentence recognition at low intensity (50dB NPS). However, various studies showed a better performance of WDRC hearing aid in speech recognition in quiet, at low levels of sound intensity (Kam and Wong, 1999; Jenstad et al., 1999; Humes et al., 1999; Souza, 2002). 
Kam and Wong (1999) did a comparative study between the linear amplification and WDRC, in 20 former users of hearing aids. They observed a better performance with the amplification WDRC in sentence recognition threshold (SRT) in quiet, and justified this finding due to the greater gain prescribed for weak sounds in this type of amplification compared to the linear one.

In the research on SRT in noise we came up with SNR of -2.75 and -2.37 in groups LG and NLG, respectively (Table 1 ). The SRT in noise test evaluates an individual's communication at low levels of sound intensity in the presence of noise. The negative values found show that speech signals were recognized at lower than noise sound pressure levels. Both the similarity of the results, and the statistical analysis performed $(\mathrm{p}=0.8)$ show that there is no significant difference between the $\mathrm{S} / \mathrm{N}$ relation, which is obtained in SRT in noise at $65 \mathrm{~dB} \mathrm{~A}$, in linear and nonlinear amplification users. These results are in accordance with Scharlach (1998). According to Kam and Wong (1999), Souza (2002) and Humes et al. (2004), in the presence of noise the nonlinear and linear hearing aid present similar benefits in relation to speech intelligibility.

However, the literature is controversial when it compares the performance of the linear and nonlinear hearing aid, in speech recognition at low intensity in noise. Some studies suggest greater progress with the WDRC amplification (Humes et al., 1999; Walden et al., 2000), the others with the linear amplification (Hornsby, Ricketts, 2001).

Scharlach (1998) studied 27 hearing impaired subjects, users of linear and nonlinear hearing aid and evaluated the SRT with noise at $65 \mathrm{~dB}$ A. The results of the SNR were 2.45 and 0.62 for linear and nonlinear amplification users, respectively. In spite of the best performance observed in the adaptation to nonlinear, these results were not statistically significant, which shows no difference between the linear and nonlinear adaptation, in the speech recognition with noise at $65 \mathrm{~dB} \mathrm{~A}$.

We analyzed possible existent correlations among different user ages, time for adaptation to the sound amplification, SRT in quiet and SNR, throughout the sample (Table 2). We can say that there is a correlation which is considered regular $(51.9 \%)$ between the SRT in quiet variables and the SNR, indicating that the increase in a variable is followed by an increase in the other. In other words, the individuals that presented higher SRT in quiet, also presented higher SNR, and vice versa.

We can understand the regular correlation found between the SRT in quiet and in noise tests
(SNR), since both evaluate the ability of speech recognition. However, if the individual does not have a good discrimination of sounds in quiet, this difficulty will probably be seen in noise, since both tasks refer to speech at low levels of intensity.

The other correlations were considered very bad or bad. Thus, we can say that the age and the hearing aid use time factors did not interfere with the results obtained in speech recognition in quiet and noise in this study. It should be borne in mind that there was a limitation as for the criteria of inclusion in this study, with the age sample ranging between 12 and 64 years old and the use time between 3 and 16 months.

Humes et al. (2004) did not find differences between objective and subjective benefits offered by the hearing aid after one month and six months of hearing aids use.

In the same manner, the age of users was correlated with the results of SNR (Table 3) by considering the linear and nonlinear hearing aid. We verified a correlation which is considered regular $(44.5 \%)$ between the increase in age and the increase in SNR in the former users of linear hearing aid, that is, the older the user is, the higher the obtained SNR. The correlation obtained in this study can be explained, once speech recognition abilities will keep deteriorating with the increase in age due to the aging of the hearing system. Thus, the speech recognition in noisy environments is even more jeopardized in older hearing aid users.

The users of hearing aids answered the IOIHA and the results were analyzed by considering the obtained score per question, through the sum total of items one to seven and through the obtained score in Factors 1 and 2, and were compared between the users of linear and nonlinear amplification (Table 4). None of the performed analyzes presented statistically significant difference between the users of linear and nonlinear hearing aid. In other words, the subjective analysis according to daily use (I1), benefit (I2), residual activity limitation (I3), satisfaction (I4), residual participation restriction (I5), impact on others (I6), and quality of life (I7) was similar in both groups studied. In the same manner, the analysis of the relation between the individual and his hearing aid (Factor 1) and of the individual and his relations with the world (Factor 2) do not differ when compared the users of the linear and nonlinear amplification circuits.

We can say that the subjective evaluation of hearing aids, which is applied in this study, does not differ between the users of linear and nonlinear 
amplification users in none of the studied aspects. This makes us believe that the amplification type (linear and nonlinear), to which the individual is exposed, does not determine a better or worse adaptation to hearing aids, at least in relation to the items evaluated in the applied questionnaire.

These results agree with Scharlach (1998), Bucuvic and Iório (2003) and Humes et al. (2004), who also studied the linear and nonlinear hearing aid comparatively through self-evaluation questionnaires. Other studies underline the users' preference for the nonlinear amplification due to the auditive comfort and normalization of the growth in sensation of the intensity (Kam and Wong, 1999; Jenstad et al., 2000; Walden et al., 2000).

We applied the IOI-HA because it is a brief, allinclusive, accessible measure of different cultural and social factors for the use and diverse comparisons (Cox et al., 2000). In this study, the focus was on the comparison of linear and nonlinear hearing aid. However, in spite of the selfexplanatory characteristic of the questionnaire, which was designed to be answered without any additional help (Cox and Alexander, 2002), in this study it was done by the researcher in charge in order to guarantee the understanding of the questions and answers, for many evaluated users had difficulty with reading and interpretation of the questions.

As again regards the IOI-HA, it can be stated that the averages obtained by item in the analyzes were positive and superior to 4 points, while it should be borne in mind that the maximum score was 5. Consequently, the analyzes of the adding up of all the questions (ST), Factors 1 and 2, were also positive, thus pointing to a good subjective result in the adaptation of the linear and non-linear hearing aids (Table 5).

Cox and Alexander (2002) also observed a high score of the evaluated individuals in his study of the questionnaire IOI-HA, thus showing favorable attitudes toward his hearting aids. He also commented on the likely sensitivity the questionnaire provides in the detection of individuals with negative experience in relation to hearing aids.

The only question with a lower average was obtained in 8 , thus suggesting that the individuals consider their hearing loss as severe or moderately severe (Table 5).

As statistically significant differences as to the subjective evaluation between the users of linear and nonlinear hearing aids were not found, the question 8 was studied considering the whole sample, regardless of the type of amplification employed. The answers to item 8 were grouped, which measured the degree of hearing aid as viewed by the user of sound amplification. The individuals that considered his hearing loss as severe or moderately severe were included in group A, while those that considered his hearing loss as moderate or slight were included in group B. No individual was included in group $\mathrm{C}$, for no user of hearing aids, in this study, considered as not having any hearing difficulties. Thus we analyzed the score obtained by item, the sum total of the items 1 through 7 and by the score obtained in Factors 1 and 2, and then we compared with he hearing difficulty in the individual (Table 5). No statistically significant differences were found in any of the analyzes performed, that is, both the individuals who presented a hearing difficulty greater than those who had complained about little hearing difficulties had similar results in the evaluation of the adaptation of hearing aids. This means that the degree of difficulty spoken of by the individual did not interfere with the subjective evaluation of the hearing aid.

Our results differed from the results found by Cox et. al (2003), who had noticed a great correlation between subjective hearing difficulty and the results obtained in the IOI-HA, thus showing that those that complained about greater hearing difficulties without the aid were those who had higher scores as to the daily use, satisfaction and quality of life. On the other hand, they presented more problems in comparison with other people.

We can be noticed, by means of both the objective and subjective evaluations done, there are no differences between the results obtained between the linear and nonlinear amplification. The agreement between the two means of evaluation has already been mentioned in other studies (Scharlach, 1998; Humes et al. 2004).

According to Hickson ad Thyer (2003), the speech perception is just an aspect of the evaluation of compression, but other measures such as perception of sound quality and user satisfaction were also important.

\section{Conclusion}

In this research, whose objective was to study and compare the performance of users of linear and nonlinear hearing aids by means of objective and subjective evaluations, the following conclusions can be drawn:

1. There are no differences in speech recognition in quiet and in noise in users of linear and nonlinear hearing aid. 
2. There are no differences in the subjective evaluation done by means of the IOI-HA between users of linear and nonlinear hearing aid.

In this manner, we could not observe any differences between users of linear and nonlinear hearing aids that either showed a better hearing adaptation or favored the speech recognition both in silence and in noise.

\section{References}

ALMEIDA, K. Avaliação dos resultados da intervenção. In: ALMEIDA, K.; IÓRIO, M. C. M. Próteses Auditivas: fundamentos teóricos e aplicações clínicas. 2. ed. São Paulo: Lovise, 2003. p. 357-379.

ALMEIDA, K.; TAGUCHI, C. K. Utilização do questionário na auto-avaliação do benefício das próteses auditivas. PróFono R. Atual. Cient., Barueri (SP), v. 15, n. 1, p. 101-110, 2004.

BUCUVIC, E. C.; Iório, M. C. M. Próteses auditivas: estudo comparativo das dificuldades auditivas e do benefício da amplificação em pacientes usuários de amplificação nãolinear e linear. R. Ci. Med. Biol., v. 2, n. 1, p. 77-87, 2003.

BUCUVIC, E. C.; IÓRIO, M. C. M. Benefício e dificuldades auditivas: um estudo em novos usuários de próteses auditivas após dois e seis meses de uso.Fono atual, v. 29, n. 7, p. 19-29, 2004.

COSTA, M. J. Lista de sentenças em português: apresentação e estratégias de aplicação na audiologia. São Paulo: Pallotti, 1998.

COX, R. M.; HYDE, M.; GATEHOUSE, S.; NOBLE, W.; DILLON, H.; BENTLER, R.; STEPHENS, D.; ARLINGER, S.; BECK, L.; WILKERSON, D.; KRAMER, S.; KRICOS, P.; GAGNÉ, J. P.; BESS, F.; HALLBERG, L. Optimal outcome mensures, research priorities, and international cooperation. Ear Hear., v. 21, n. 4, p. 106S-115S, 2000.

COX, R. M.; ALEXANDER, G. C. The international outcome inventory for hearing aids (IOI-HA): psychometric properties of the english version. Int. J. Audiol., v. 41, n. 1, p. 30-35, 2002.

COX, R. M.; STEPHENS, D.; KRAMER, S. E. Translation of the international outcome inventory for hearing aids. (Tradução para o Português de Maria Cecília Belivacqua et al.) (IOI-HA). Int. J. Audiol.,v. 41, n. 1, p. 3-26, 2002.

COX, R. M.; ALEXANDER, G. C.; BEYER, C. M. Norms for the international outcome inventory for hearing aids. J. Am. Ac. Audiol., v. 14, n. 8, p. 403-413, 2003.

DAN, I. B.; IÓRIO, M. C. M. Dificuldade e desvantagem auditivas: estudo em idosos na adaptação de próteses auditivas. Fono atual, v. 29, n. 7, p. 0-59, 2004.

HICKSON, L.; THYER, N. Acoustic analysis of speech through a hearing aid: perceptual effects of changes with two channel compression. J. Am. Acad. Audiol., v. 14, n. 8, p. 414-426, 2003.

HORNSBY, B. W. Y.; RICKETTS, T. A. The effects of compression ratio, signal-to-noise ratio, and level on speech recognition in normal-hearing listeners. J. Acoust. Soc. Am., v. 109, n. 6, p. 2964-2973, 2001.

HUMES, L. E.; CHRISTENSEN, L.; THOMAS, T.; BESS, F. H.; HEDLEY-WILliAMS, A.; BENTLER, R. A comparison of the aided performance and benefit provided by a linear and two-channel wide dynamic range compression hearing aid. J. Speech. Lang. Hear. Res., v. 42, n. 1, p. 65-79, 1999

HUMES, L. E.; HUMES, L. E.; WILSON, D. L. A comparison of single-channel linear amplification and twochannel wide-dynamic-range-compression amplification by means of an independent-group design. Am. J. Audiol., v. 13, p. 39-53, 2004.

JENSTAD, L. M.; SEEWALD, R. C.; CORNELISSE, L. E.; SHANTZ, J. Comparison of linear gain and wide dynamic range compression hearing aid cicuits: aided speech perception meansures. Ear Hear., v. 20, n. 2, p. 117-126, 1999.

JENSTAD, L. M.; PUMPFORD, J.; SEEWALD, R. C.; CORNELISSE, L. E. Comparison of linear gain and wide dynamic range compression hearing aid circuits II: aided loudness meansures. Ear Hear., v. 21, n. 1, p. 32-44, 2000.

KAM, A. C. S.; WONG, L. L. N. Comparison of performance with wide dynamic range compression and linear amplification. J. Am. Acad. Audiol., v. 10, n. 8, p. 445-457, 1999.

LINDLEY, G. Normal aided functioning: pipe dream or possibility? Hear. J., v. 55, n. 7, p. 10-20, 2002.

MENEGOTTO, I. H.; IÓRIO, M. C. M. Processamento do sinal sonoro nas próteses auditivas: compressão. In: ALMEIDA, K.; IÓRIO, M. C. M. Próteses Auditivas: fundamentos teóricos e aplicações clínicas. 2. ed. São Paulo: Lovise, 2003. p. 119-148.

SCHARLACH, R. C. Estudo comparativo do desempenho de próteses auditivas com circuito K-amp e limitação por compressão. 1998. xx f. Dissertação (Mestrado em Distúrbios da Comunicação Humana) - Universidade Federal de São Paulo, São Paulo.

SOUZA, P. E. Effects of compression on speech acoustics, intelligibility, and sound quality. Trends Amplific., v. 6, n. 4, p. 131-160, 2002.

WALDEN, B. E.; SURR, R. K.; CORD, M. T.; BRENT, E.; OLSON, L. Comparison of benefits provided by different hearing aid technologies. J. Am. Acad. Audiol., v. 11, n. 10 , p. 540-60, 2000.
These findings reinforce the idea that the
daptation of hearing aids is an individual and personalized task, and, therefore, the
characteristics of amplification should provide hearing satisfaction peculiar to each user, signal .

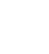

